\title{
Variation in ethnonym-based names of clothing items in Russian dialects: a cultural and sociolinguistic study
}

\author{
Oksana Marunevich ${ }^{1 *}$, and Valentina Kolmakova ${ }^{2}$ \\ ${ }^{1}$ Rostov State Transport University, 2 Rostovskogo Strelkovogo Polka Narodnogo Opolcheniya Sq., \\ Rostov-on-Don, 344038 Russia \\ ${ }^{2}$ Don State Technical University, 1 Gagarin Sq., Rostov-on-Don, 344000, Russia
}

\begin{abstract}
Though modern linguistics pays great attention to the theory of nomination, in particular to the study of thematic groups, the dialectic names of clothing items are among the least commonly investigated types of words. Indeed, no one to the best of our knowledge has addressed the question of ethnonym and toponym-based names of clothes in a variety of Russian dialects. The aim of the present study is to broaden current knowledge of the given issue. The core problem of the given paper is the nominative models of the ethnonym and toponym-contained names of clothing items in Russian dialects and their analysis from cultural and sociolinguistic perspectives. Based on numerous examples, the authors single out the major nominative models of clothing vocabulary and come to the conclusion that word combinations are a striking feature of the Russian dialects since they more accurately specify the object.
\end{abstract}

\section{Introduction}

Since the second half of the twentieth century, the systemic organization of diverse levels of the language is undergoing considerable interest. There is no doubt that the word as a unit of language is characterized by independence and autonomy. On the other hand, one cannot deny the connection between words and groups of words. Being the minimum nominative unit, the word has a huge potential for naming various objects of the surrounding reality, and a limited corpus of lexemes serves as the basis for naming an unlimited number of objects.

It should be noted that in modern linguistics there is no generally accepted classification of lexical associations, despite the fact that the ideas about the existence of certain groups of words were expressed by W. Humboldt, G. Ostgof, G. Ipsen, A.A. Potebnya, M.M. Pokrovsky in the late XIX - early XX centuries. In particular, back in 1896 a prominent Russian linguist M.M. Pokrovsky noted that "words and their meanings do not live a separate life from each other, but are united in our soul, regardless of our consciousness, into different groups" [1]. The term "semantic field" as a linguistic one had for the first time been employed in 1924 by Austrian philologist Günther Ipsen in his paper

\footnotetext{
${ }^{1}$ Corresponding author: oks.marunevich@mail.ru
} 
'Der alte Orient und die Indogermanen'. Ipsen exploited the term in the compound Bedeutungsfeld to characterize a group of words that together form a unit of meaning as, for instance, the Indo-European vocabulary for 'sheep' and 'sheep raising' [2].

As stated by G. Changhong, the semantic field theory then matured thanks to Jost Trier, who in the 1930s proposed that a group of words with interrelated meanings could be categorized under a larger group [3]. For instance, the words hippo, muskrat, wolf, zebra, octopus fall under the semantic category of animals.

A recent review of the literature on this topic found that systemic relations in the vocabulary are extremely complicated and there is much discussion on large conceptual domains known as lexical-semantic groups (P. Filin, V. Gak, A. Ufimtseva), semantic paradigms (D. Shmelev), thematic groups (I. Arnold, O. Akhmanova, I. Olshansky, E. Mednikova), lexical-semantic systems (V. Zvegintsev), invariant and functional classes (G. Shchur), word field, lexical field, field of meaning, or semantic system (R. Nordquist), semantic similarity space (Vigliocco, Vinson, Damian, \& Levelt). For instance, R. Nordquist defines the semantic field as a set of lexemes that being grouped in a conceptual domain (body parts, animals, colors, professions, kinship relations, etc.) bear certain relations to one another, as well as share a common semantic property [4]. R. Grandy focuses that a semantic field can be very large or very small, depending on the level of contrast between lexical items [5]. G. Vigliocco et al. strongly believe that within semantic similarity space, some words are more central to the category (typical), while others are less central to it (atypical) [6]. D. Crystal reported on the need to consider context before including a word to a particular field, "for example, hospital relates to both the semantic field of health (as in 'I was in the hospital last week') and that of buildings (as in "The hospital needs a new roof)" [7]. Yu. Karaulov calls into question some past assumptions about the aforementioned term. In his book, the distinctions between semantic field (e.g. semantic field love) and lexico-semantic group (e.g. a group of words with the meaning alteration), thematic group (e.g. thematic group plant names), synonymous series (e.g. a series with the invariant meaning bold), onomasiological group (e.g. the concept distance expressed by nouns/adjectives) is explained by giving supporting examples [8].

\section{Materials \& methods}

Semantic fields which resemble the original ones of Ipsen and Trier are often used as a basis for the investigation of parts of the vocabulary. Such fields provide a naturally demarcated area of research. This study was undertaken to examine the semantic field "clothing", and more specifically, ethnonym and toponym-marked vestonyms (Latin vestis - clothing), i.e. words denoting individual items or details of clothing and footwear. The names of clothing items are can be found in all languages, without exception. Indeed, clothing is a key element of the national culture of society, and prior to the 20th century, clothing, along with language, religion, habitation, and historical memory of an individual, was also a marker of their ethnic identification. However, this issue is a neglected area in both Russian and Western linguistics.

We analyzed Russian dialectic vestonyms that contain an ethnonym or toponym. Our steps proceed very much in the same way as indicated in [9]. Fig. 1 indicates the map of the dialects under study. The corpus of lexical units includes 618 separate words and word compounds discovered in dictionaries of Russian dialects. The key significance of dialects lies in the absence of any political correctness and restrictions in terms of word formation and secondary nomination. Besides, in contrast to the literary language, they still rapidly react to diverse social, political or historical processes, which greatly affect the emergence of new words or meanings of the word, e.g., афганка (Afghan) - a military uniform worn by members of the Soviet and Russian Armed Forces < allusion to the Afghan war (1979- 
1989).

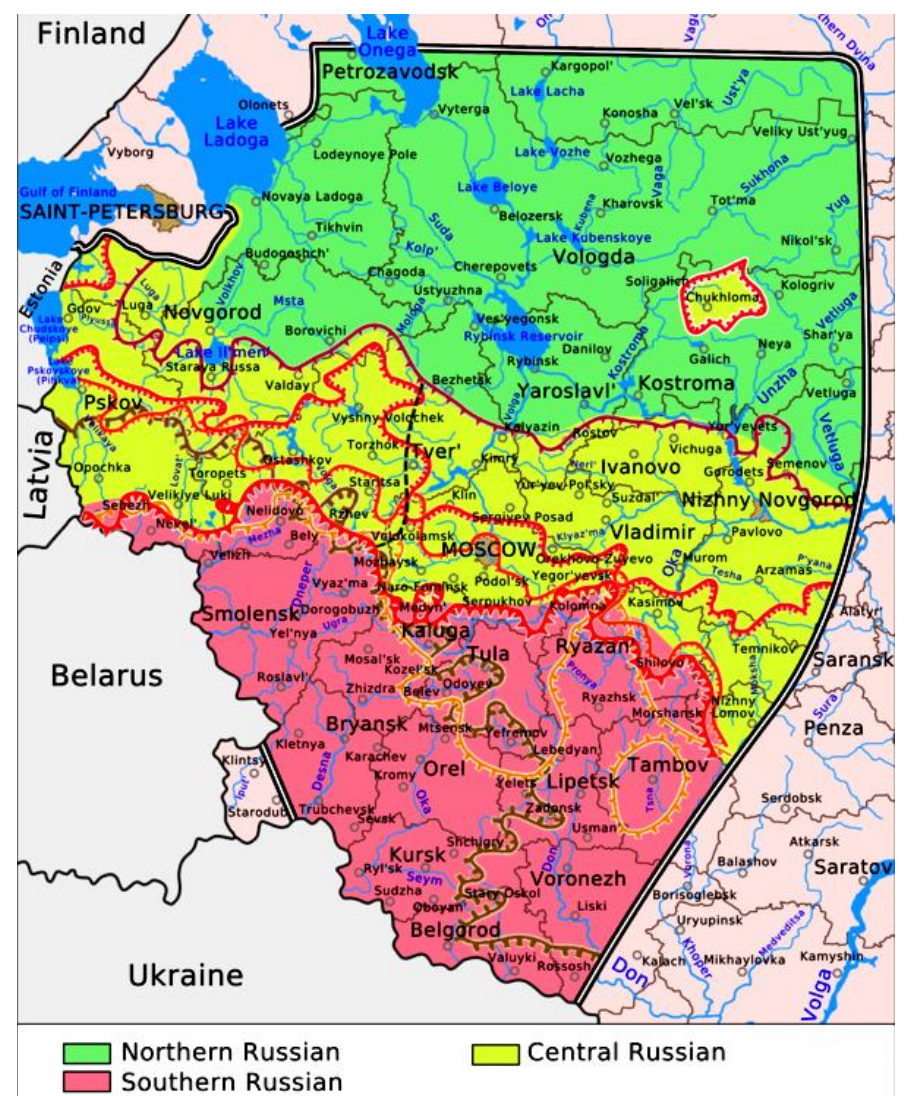

Fig. 1. Map of the Russian dialects under study.

\section{Results}

The earliest use of одёжа (clothes) in Russian came in the 9th century, as a noun whose etymology goes back to the Proto-Slavic *odedja [10]. The Proto-Slavic * odedja $<*$ obdedja was formed by adding the prefix $o b$ - and the suffix $-j-a$ to the root $*$ ded-, which was an incomplete repetition of the root dě- $(d e-d-)$ of the verb *děti $>$ to put. In the 18th century, it was replaced by the Church Slavonic одежда, found in the "Lexicon of the Trilingual" by Fedor Polikarpov-Orlov (1704) [11]. It is interesting to note that одеждa (clothes) is closely related to the надежда (hope) since both of them come from the Old Church Slavonic dezhd $\mathrm{k}$ - to put [10].

The majority of Russian language dictionaries interpret clothes as "a set of material items that cover, clothe the body" [12]. These material items are designed to shield the human body from the external threats of the environment [13], as well as from physical, social, emotional, and spiritual threats, real and imagined [14].

D. Ushakov defines clothing as "a set of issues (made of fabric, fur, leather) that cover, dress the body" [15]. T. Efremova gives a more extended definition: "1. A set of items (fabric, fur, leather, etc.) that cover the body or put on it. 2. Some of these items, excluding linen, shoes, hats; dress. 3. smth that is worn by smb" [16].

At the same time, it is rather difficult to define the given word due to the lack of a generally accepted viewpoint. For example, Vladimir Dal points out that clothing is items 
worn on the body, excluding hats, gloves, and shoes [17]. D. Ushakov does not consider underwear, footwear, and hats to be clothing items [15]. In this paper, we will use the term clothing to refer to underwear, dress, hosiery, footwear, and hats. Although some authors consider it incorrect to include footwear and hats in the category of clothing [18], this contradiction is partly solved by V. Lipskaya, who considers clothing to be a component of a costume, a set of individual things and accessories [19].

From the Mousterian era (100,000-40,000 years ago) clothing as a basic human need serves triple functions [20]. The protective function is associated with the geographic and climatic conditions of human habitats. The first loincloths and cloaks were a means to protect the vulnerable naked human body from external influences (sun, cold, wind, rain). Subsequently, the "wardrobe" of ancient people was enlarged with stockings and oversleeves. Sewn clothes appeared in the Upper Paleolithic era (40,000-12,000 years ago). The archaeological excavations in the Ötztal Alps made it possible to learn more about the Bronze Age costumes. The well-preserved mummy of a hunter was dressed in a woven grass cape, believed to be a prehistoric raincoat, fur leggings, and goatskin undergarments, straw insulated leather shoes, a coat of leather and goat fur, and a brown-bear-fur hat [21].

In the Ancient East and Ancient Hellas, clothing began to perform an informative function. From the scientific point of view, clothing is a part of material culture created by human labor. Paradigmatic Social and economic changes have a huge impact on fabric manufacturing technology and fashion. In addition, clothing is a kind of manifestation of the aesthetic ideals of the era. Indeed, "clothing provides a remarkable picture of the daily lives, beliefs, expectations, and hopes of those who lived in the past [22]. For example, in Ancient Mesopotamia, wool was the most common fabric utilized to make every type of garment. Men of high status, such as kings and priests wore linen clothes dyed yellow, bright red, red-brown, apple-green, blue, and red-purple. In Greece, linen was available to everyone, while soft cotton was a more luxurious fabric. The ancient Greek male's chiton, himation and chlamys, female's chiton, peplos, chlaina, and diplax followed the laws of symmetry and indicated the natural curves of the body beneath the drapery [23].

Besides, clothes are an individual's "passport" that reveals their gender, age, origin, marital and social status. Before the English Civil War (1642-1651), clothing was a cultural code, whose violation was considered an assassination attempt on the divine world order [24]. For instance, in Assyria and Babylon, soldiers were required to wear trousers, while the rest of the male population wore tunics. In ancient Greece, slaves were obliged to wear a tunic with an unsewn bottom. In Ancient Rome, the toga praetexta with a wide purple edging could be worn only by curule magistrates, priests, and freeborn boys and girls until adulthood. The poorest population avoided wearing a toga. Married citizen women wore a stola, a women's tunic up to the ankles. Women of easy virtue, slaves, and freedwomen were strictly forbidden to wear the stola. In Russia, there was a distinction between a sarafan and a poneva-type costume worn by the inhabitants of the northern and southern regions of the country, respectively. Married women of the pre-Petrine era wore a povoinik and a kika on their heads, and girls wore a wreath with wide ribbons behind.

Finally, clothing has a sacred function. L. Toporkov emphasizes that when facing outward, clothes aim to manifest social values; while facing inward, towards the body, it possesses the magical power of the naked body and hair, human warmth, physiological functions. Clothes acts as a mediator, a line where the inner turns into the outer, physiology and corporeality metamorphose into culture and sociality [25]. It is no accident that garments were frequently used in folk rites since they had ritual and symbolic meaning. For instance, in the Ryazan region, on her wedding day, the bride first put on a "miserable" poneva with a white canvas stitching, which much resembles grave clothes, only after the wedding ceremony, it was changed into festive attire [26]. In the Arkhangelsk region, the bride's head was covered with a kukol, a deceased's burial headwear [26]. In our opinion, 
the aforementioned rituals are associated with the bride's liminal status of being neither dead nor alive, which is especially typical for weddings of the Russian North. The wedding-funeral type occurs as a metaphor for death, so the mother and girlfriends of the bride cried seeing the girl in a wedding dress. If the spouse of the deceased wanted to marry again, the collar of the shirt was left unbuttoned [26]. In case of difficult childbirth, the midwife untied her apron and hung it on the shoulders of the woman in labor, while her husband untied the collar of his shirt and the belt of his pants. In Belarus, to help with pain during labor, the husband dressed in women's clothes or tied his head with a scarf and moaned [26]. To protect against evil forces, or, on the contrary, to increase luck, people decorate collars, sleeves, and hemlines with embroidery. So, the rhombus means fertility, apples, and horseshoes were symbols of love and luck, respectively.

Turning now to the aim of our study, it is possible to state that the vocabulary of any language includes ethnonym and toponym-marked words. As a rule, this is a separate lexeme or phrase with an "ethnic" component exploited to nominate household items, dishes, clothes, plants, etc., common in a particular country [27]: норвежки (Norwegians) - skis lined with fur; шведка (Swede) - stove with a covered stove and oven; цыганка (Gypsy woman) - boiled potatoes with hemp oil; жидовская вишня (Jеw's cherry) Physalis Alkekengi; китайские церемонии (Chinese ceremonies) - tiresome and unnecessary ceremonies.

In these phrases, ethnic components indicate a certain nation that widely uses this or that item in the everyday routine. At the same time, they reflect the historical and linguistic image of another culture and its bearers since the transfer of cultural and historical experience is conditioned by multiple factors, including social, semantic, and value-activity ones [28]. However, it is worth noting that the number of borrowings always prevails over names that record the fact of borrowing. Therefore, the question of why a particular ethnonym-marked item appeared in the recipient language is of great interest to researchers. In particular, since the 17th century, the British have borrowed from the French a wide array of items from fashion, cooking, and art industries, however, their French origin can be traced only in the names of a few: French dressing - seasoning for vegetable oil salad, wine vinegar and Dijon mustard, French fries - fried potatoes, French bread - long loaf, baguette, French braid - braid style, where hair is gathered gradually from the sides of the head over the course of braiding, French window - panoramic window from ceiling to floor, French roof - mansard roof, French chalk - tailor's chalk, French suds - champagne, French heel - a curved, high heel, Frenchman's acre - hectare, French maid - a trope comic character in theater and opera.

The study of ethnonym and toponym-marked vestonyms has attracted our interest due to several reasons. First, it assists in reconstructing the historical past of this or that nation, determining the territory of their habitat, identifying cultural, commercial, etc. links with closest neighbors. Second, they are a source of stereotyped knowledge about out-group members, their habits, and their way of life. Indeed, the binary notion "in-group - out-group member" can be found in language, mythology, beliefs, omens, and everyday routine [29].

The careful analysis of Russian dialectic ethnonym and toponym-marked vestonyms has enabled the identification of the nomination models as follows:

1. Continent + vestonym, e.g. американская пройма (American armhole) - a deep, open-shouldered diagonal cut from the armpits to the neckline on a dress, blouse or top, which became fashionable after the comedy "The Seven Year Itch" (1955) starring Marilyn Monroe.

2. Country + vestonym, e.g. английский воротник (English collar) - a collar with fused wider collar points which are angled outwards; франиузский воротник (French collar) - a collar with outward-angled collar points of various shapes (sharp, rounded, cut, etc.); франиузский платок (French scarf) - a cotton scarf; франиузский фрак (French 
tailcoat) - a tailcoat with cuts along the sides; голландские портки (Dutch pants) - holey, short, unwearable pants; датский сарафан (Danish sarafan) - a sarafan made of colored chintz; картуз норвежский (Norwegian cap) - a cap with front and back visors; русская шуба (Russian fur coat) - a fur coat with fur inside.

Furthermore, the aforementioned nominative model includes the names of clothing items based on:

a) a separate ethnonym, e.g., голландка (Dutch) - a flannel sailor shirt; shirt; японка (Japanese) - the cut of the sleeves of a woman's dress that resemble a Japanese kimono; агличник (English) - an elegant colored chintz sarafan; татарка (Tatar) - a special sheep's fur coat; winter men's cone-shaped round hat, trimmed with fur at the bottom; болгарка (Bulgarian) - a bride's cap embroidered with ribbons and decorated with flowers; румынки (Romanians) - women's boots without a fur edge on a low, thick heel; черкеска (Circassian) - a narrow long caftan, tightened at the waist, without a collar and with a wedge-shaped cut on the chest; цызаны (gypsies) - leather footwear;

b) an attributive word combination, consisting of an ethnonymic adjective and a vestonym, е.g., мордовские лапти (Mordovian bast shoes) - bast shoes that are worn with large white onuchs and long fringes; черемисские лапти (Cheremis bast shoes) - bast shoes with a blunt end; марийские лапти (Mari bast shoes) - bast shoes with a square, box-shaped end; аглиикая фатка (English veil) - an elegant chintz shawl.

The most remarkable result to emerge from the data is that Russian folk dialects (Arkhangelsk, Vologda, Kostroma, Karelian, Yaroslavl, Vladimir, etc.) contain the abundance of derivatives from the word English, e.g., аглинь - a fabric of English origin; аглиикий ситеи - cotton fabric dyed bright red; аглиикой / агличной - a clothing item sewn from red-colored chintz; аглиикий - bright fabric with a colored pattern; агличник - a sarafan made of bright fabric with a colored pattern; английка - a shawl made of thin expensive woolen fabric; аглечуха - a headdress embroidered with beads or bugles, worn by married peasant women. However, as stated by E. Berezovich, these lexemes do not indicate England as the country of origin. Moreover, азлиџкие платки (English shawls) were the official trade name of shawls manufactured at factories of the Russian Empire in the 19th century. Referring to the data from the "Dictionary of Russian folk dialects", the researcher concludes that English here is synonymous with foreign, solid, elegant, and beautiful [30].

3. The model vestonym + geographic region is presented by a few examples, e.g., сибирка (Siberian) - a hat with earflaps; short fitted caftan with a standing collar; longsleeved, double-breasted coat with a turndown collar and lapels on the chest; тирольская шляпа (Tyrolean hat) - a green felt hat with a crown tapering to a point.

4. The nominative model is vestonym + island is not presented in Russian dialects. However, the modern Russian literary language is an excellent source of such model, e.g., аранский свитер (Aran juтреr) - a sweater made of undyed cream-colored sheep wool with cable patterns on the body and sleeves $<$ Aran Islands, located off the west coast of Ireland. According to Irish legends, the stitches symbolize the ropes of the fisherman and are a wish for good luck. Moreover, due to the variety of patterns, in the old days, each jumper was unique, thus helping to identify the bodies of drowned fishermen [31]; бикини (bikini) -a women's two-piece swimsuit < Bikini Atoll in the Pacific Ocean, where on July 1, 1946, the first public test of nuclear bomb took place. Clothing designer Louis Reard strongly believed that girls wearing his swimsuits on the beach would cause the same sensation as an atomic explosion; капри (capri pants) - women's three-quarter trousers < Capri island in the Gulf of Naples, Tyrrhenian Sea.

5. The model vestonym + name of the city is represented by just two examples, e.g., московский сарафан (Mоscow sarafan) - a wedge-shaped sarafan, whose panels are 
collected at the top in small folds or assemblies; берлинский пояс (Berlin belt) - a homespun belt made of colored woolen threads.

Unfortunately, the scope of the paper does not allow giving all examples, but Fig. 2 summarizes the data on the distribution of nominative models over the lexeme corpus.

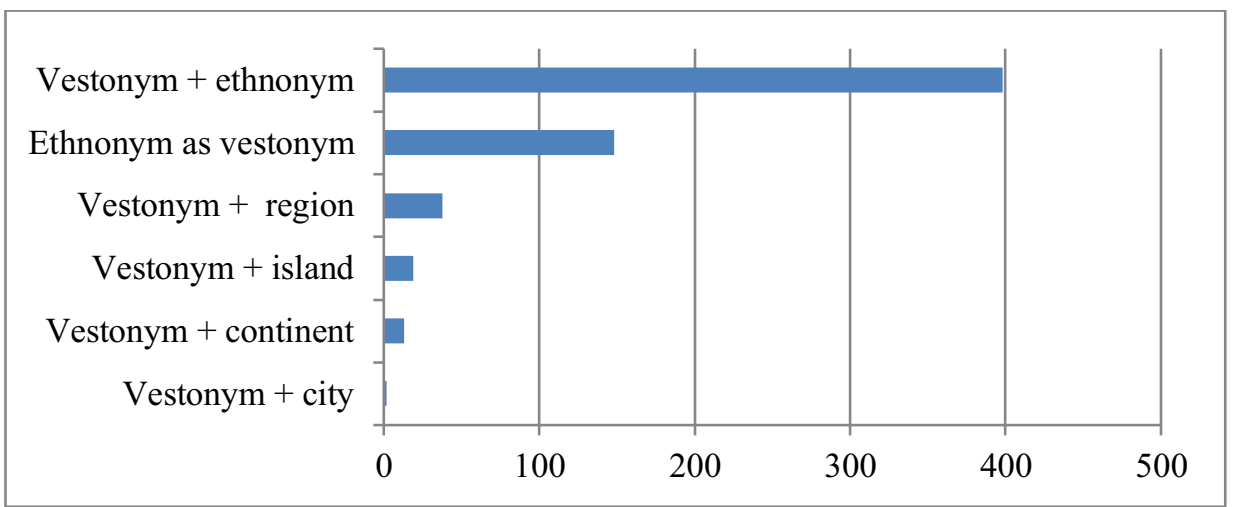

Fig. 2. Nominative models of dialectic clothing items (in descending order).

As illustrated in Fig. 2, in Russian dialects, the nominative models of clothing items are very unevenly distributed: at one extreme is the nominative model "vestonym + ethnonym" presented by 398 lexical units out of 618 , and at the other is the model "vestonym + city" presented by 2 word combinations only.

Table 1 summarizes the data on the most mentioned ethnic groups in vestonyms of Russian dialects.

Table 1. Top-10 ethnic groups of Russian dialectic vestonyms.

\begin{tabular}{|c|c|c|}
\hline Ethnonym & Occurrence frequency & Example \\
\hline Russian & $78(14.2 \%)$ & $\begin{array}{c}\text { русская камлея (Russian coat) - outerwear with fabric hood } \\
\text { русские сапоги (Russian boots) - crotch high boots } \\
\text { pусские исподки (Russian mittens) - one needle-sewed mittens }\end{array}$ \\
\hline English & $42(7.7 \%)$ & $\begin{array}{c}\text { англечник (English) - dress made of dense red chintz } \\
\text { аглицкой платок (English shawl) - red shawl with an intricate pattern } \\
\text { аглецкая рубашка (English shirt) - neat red men's shirt }\end{array}$ \\
\hline Chinese & $24(4.4 \%)$ & $\begin{array}{l}\text { китайчник (Chinese) - dress made of one-color fabric } \\
\text { китаечка (Chinese) - bright ribbon } \\
\text { китайник (Chinese) - black clothes of the Old Believers }\end{array}$ \\
\hline Dutch & $19(3.5 \%)$ & $\begin{array}{c}\text { голландка (Dиtch) - women winter coat with large collar } \\
\text { галанка (Dutch) - sheepskin coat } \\
\text { голанка (Dutch) - elegant men's dress shirt }\end{array}$ \\
\hline Tatar & $18(3.3 \%)$ & $\begin{array}{c}\text { татарка (Tatar) - men's and women's outerwear of special cut } \\
\text { mатарская шапка (Tatar cap) -cap without ears with a narrow fur trim }\end{array}$ \\
\hline German & $16(2.9 \%)$ & $\begin{array}{l}\text { немецкая шаль (German shawl) - any abroad-made shawl } \\
\text { немецкий чулок (German stocking) -knee high stocking }\end{array}$ \\
\hline Hungarian & $11(2 \%)$ & $\begin{array}{c}\text { венгерка (Hungarian) - short women's coat or long warm jacket } \\
\text { венгерка (Hungarian) - ankle boots }\end{array}$ \\
\hline Ukrainian & $11(2 \%)$ & $\begin{array}{l}\text { хохлаикая рубаха (Ukrainian shirt) - men's shirt with cufflink or string } \\
\text { украинские сапоги (Ukrainian boots) - red morocco leather boots }\end{array}$ \\
\hline Spanish & $8(1.4 \%)$ & $\begin{array}{l}\text { испанка (Spanish) - black headscarf tied on bobbins } \\
\text { испанская шаль (Spanish shawl) - fringed silk shawl }\end{array}$ \\
\hline Other & $319(58.4 \%)$ & $\begin{array}{c}\text { самоедка (Samoyed) - winter hat } \\
\text { цыганы (gypsies) - leather footwear } \\
\text { французский платок (French scarf) - a cotton scarf } \\
\text { шведка (Swedish) - men's short sleeve shirt } \\
\text { белорусские лапти (Belarus bast shoes) - bast shoes with direct weaving }\end{array}$ \\
\hline
\end{tabular}

From the table above, we can see that $51.6 \%$ of ethnonym-based names of clothing items in Russian dialects contain such ethnic groups as Russian, English, Chinese, Dutch, 
Tatar, German, Hungarian, Ukrainian, and Spanish. It is crucial to note that only Ukrainians and Tatars belong to the inner circle of Russian ethnic image of the world, which includes nations close to Russian in terms of language, confession, customs, and traditions (Ukrainians, Byelorussians), as well as nations, whose territories were annexed to Russia long ago (the peoples of the Caucasus, the Volga region, and Siberia) [32]. The rest is represented by European ethnonyms. The given fact can be explained by the wide exchange of goods between Russian and neighboring countries and consumers' tendency to purchase foreign products and view them as symbols of status and wealth. Other nations (Mordvin, Swedish, Vogul, French, etc.) are represented by $58.4 \%$ of our corpus.

As far as we are aware this is the first time that ethnonym and toponym-based names of clothing items were examined from cultural and sociolinguistic perspectives. The abovementioned examples manifest that such words and word combinations are richly represented in Russian dialects. It is hardly possible to overestimate the significance of the given categorization as it is one of the key dimensions along which we perceive and introduce order into our environment [33].

\section{Conclusion}

To sum up, our study provides considerable insight into the semantic field clothing in Russian dialects. Our work has led us to conclude clothing items are the most important part of the material culture of any nation. Their names, purpose, and functions change over time under the influence of social, economic, political, or ideological factors. At the same time, the language is flexible enough to reflect these changes timely. An analysis of the corpus of ethnonym and toponym-marked vestonyms of the Russian dialects testifies to the asymmetry of their nominative models. The results of this study suggest that the model "ethnonym as a nominative feature" is the most common to name the garments in Russian dialects, while the model "vestonym + name of the city" is the most poorly used one.

Our investigations into this area are still ongoing. We are currently in the process of investigating ethnonym and toponym-marked vestonyms of the English dialects. Besides, further work needs to be carried out to establish whether there are any similarities between both languages.

\section{References}

1. M. Pokrovsky, Semasiological research in the field of ancient languages (1896)

2. G. Ipsen, Stand und Aufgaben der Sprachvwissenschaft, Winter, 200-237 (1924)

3. G. Changhong, Chinese Journal of Applied Linguistics, 33(3), 51-51 (2010)

4. R. Nordquist, ThoughtCo, April, (2019)

5. R. Grandy, Frames, Fields, and Contrasts: New Essays in Semantic and Lexical Organization (2012)

6. G. Vigliocco, D. Vinson, M. Damian, \& W. Levelt, Cognition, 85, B61-B69 (2002)

7. D. Crystal, An Encyclopedic Dictionary of Language and Languages (1992)

8. Y. Karaulov, Philological Sciences, 1, 57-68 (1972)

9. D. Shalkov, V. Kolmakova, E. Shilova, Modern Global Economic System: Evolutional Development vs. Revolutionary Leap, DOI: 10.1007/978-3-030-69415-9 (2021)

10. M. Vasmer, Etymological dictionary of the Russian language (1987) 
11. F. Polikarpov-Orlov, The lexicon is trilingual, that is, sayings of the Slavic, HellenicGreek, and Latin treasures from various ancient and new books, collected and in the order of the Slavic alphabet (1704)

12. S. Ozhegov, N. Shvedova, Dictionary of the Russian language (2006)

13. E. Plaksina, History of the costume. Styles and directions (2004)

14. E. Harms, American Journal of Sociology, 44 (2), 239-250 (1938)

15. D. Ushakov, Dictionary of the Russian Language (2014)

16. T. Efremova, New Dictionary of the Russian Language (2000)

17. V. Dal, Dictionary of the Living Great Russian Language (2006)

18. E. Starovoitova, Theoretical, methodological, technological aspects of the phenomenon "Fashion for clothes" in cultural discourse (2017)

19. V. Lipskaya, Culturology, 2, 107-110 (2013)

20. E. Kireeva, Costume history: European costume from antiquity to the 20th century (1970).

21. V. Coia, G. Cipollini, P. Anagnostou, F. Maixner, et al., Scientific Reports, 6 (2016), DOI: $10.1038 /$ srep 18932

22. L. Baumgarten, What Clothes Reveail (2002)

23. S. Pendergast, T. Pendergast \& S. Hermsen, Fashion, Costume, and Culture: Clothing, Headwear, Body Decorations, and Footwear through the Ages (2004)

24. R. Bart, Art magazine, 18 (1997)

25. A. Toporkov, Ethnographic study of the symbolic means of culture (1989)

26. G. Maslova, Folk clothes in East Slavic traditional customs and rituals of the 19th early 20 th centuries (1984)

27. O. Marunevich, Bulletin of the Irkutsk State Linguistic University, 1, 43-49 (2010)

28. V. Kolmakova, D. Shalkov, O. Baryshnikova, Innovative Technologies in Science and Education, 210 (2020), https://doi.org/10.1051/e3sconf/202021018023

29. O. Marunevich, A. Kononenko, Russian Linguistic Bulletin, 2(22), 33-37 (2020), DOI: https://doi.org/10.18454/RULB.2020.22.2.24

30. E. Berezovich, Anthropological Forum, 2, 174-212 (2019)

31. S. Carden, Costume, 48 (2), 260-275 (2014) DOI: 10.1179/0590887614Z.00000000053 (2014).

32. O. Marunevich, Concept "Foreigner": Lingvocogntive and axiological aspects (on material of Russian and English languages) (2009)

33. O. Marunevich, I. Kotliarenko, O. Bessarabova, E. Shefieva, T. Bobrova, Modern Global Economic System: Evolutional Development vs. Revolutionary Leap, https://doi.org/10.1007/978-3-030-69415-9_57 (2021). 